\title{
Making a case for national surgery, obstetric, and anesthesia plans
}

\author{
Isabelle Citron, BmBCH, MPH (1) - Kristin Sonderman, MD, MPH • Leonard Subi, MD, MPH • \\ John G. Meara, MD, DMD, MBA
}

Received: 14 September 2018/Revised: 1 October 2018/Accepted: 2 October 2018/Published online: 11 December 2018 (C) Canadian Anesthesiologists' Society 2018

The United Nations' 17 sustainable development goals (SDGs) target a wide range of human conditions worldwide, including poverty, equity, development, gender, health, and prosperity. ${ }^{1}$ Annually, 16.9 million lives are lost because of surgically amenable conditions, $\$ 12.3$ trillion of economic productivity will be lost between 2015 and 2030 because of diseases related to surgery, anesthesia, and obstetric (SOA), and 81 million people each year face catastrophic expenditure seeking surgical care. $^{2}$ Given that emergency and essential surgery and anesthesia care became part of universal health coverage (UHC) in 2015, and SOA care directly underpins six of the 17 SDGs, a massive movement in global public health is needed to meet the UHC and SDG targets. ${ }^{3}$ Efforts must address the entire surgical system, from the community level right through to complex tertiary referral care deploying a trans-professional strategy across all domains of the health system. The human rights and economic arguments for investment in SOA care are clear; there is now a mandate to act.

\section{Access to surgical and anesthesia care}

The true notion of "access" to SOA care is complex. There are a number of interdependent factors that must align

I. Citron, BmBCH, MPH $(\varangle) \cdot$ K. Sonderman, MD, MPH

J. G. Meara, MD, DMD, MBA

Department of Global Health and Social Medicine, Harvard

Medical School, Boston, MA, USA

e-mail: Isabelle.Citron@gmail.com

L. Subi, MD, MPH

Directorate of Preventative Services, Ministry of Health of

Tanzania, Dar es Salaam, Tanzania before access becomes a reality for patients. First, care must be available when a patient arrives at the health facility where the service is offered. The services must be provided by skilled providers, and should be of sufficient quality to provide the desired outcomes. In addition, the care must be usable, which means that patients must be able to overcome the multiple barriers, such as education, geography, and affordability that prevent them getting to and using available care. Lastly, affordability is a doubleedged sword - it can act as a barrier to prevent some from seeking, reaching, or receiving care, or for those who do receive care, it can then push them into poverty, resulting in a perverse trade-off between health and wealth. ${ }^{4}$

Given the true meaning of "access", it is clear that these issues exist to different extents in almost all healthcare systems, not just those in low-income countries. In some low-income countries, availability, quality, usability, and affordability may all be a problem. This is reflected, for example, in the fact that patients are still almost twice as likely to die following surgery in some African countries, pointing to poor patient health literacy resulting in delayed presentation and poor availability and quality of care. ${ }^{5}$ High income countries also have issues with access. For example, over $70 \%$ of the approximately 30 million uninsured patients in the USA are at risk of catastrophic expenditure from trauma care. ${ }^{6}$ Furthermore, in terms of quality of care, the USA has a rising maternal mortality rate with mothers $55 \%$ more likely to die in the USA than in Libya. ${ }^{7}$ If access to SOA care is to be improved, all these elements of true "access" must be simultaneously addressed, and as such, coordination is key. 


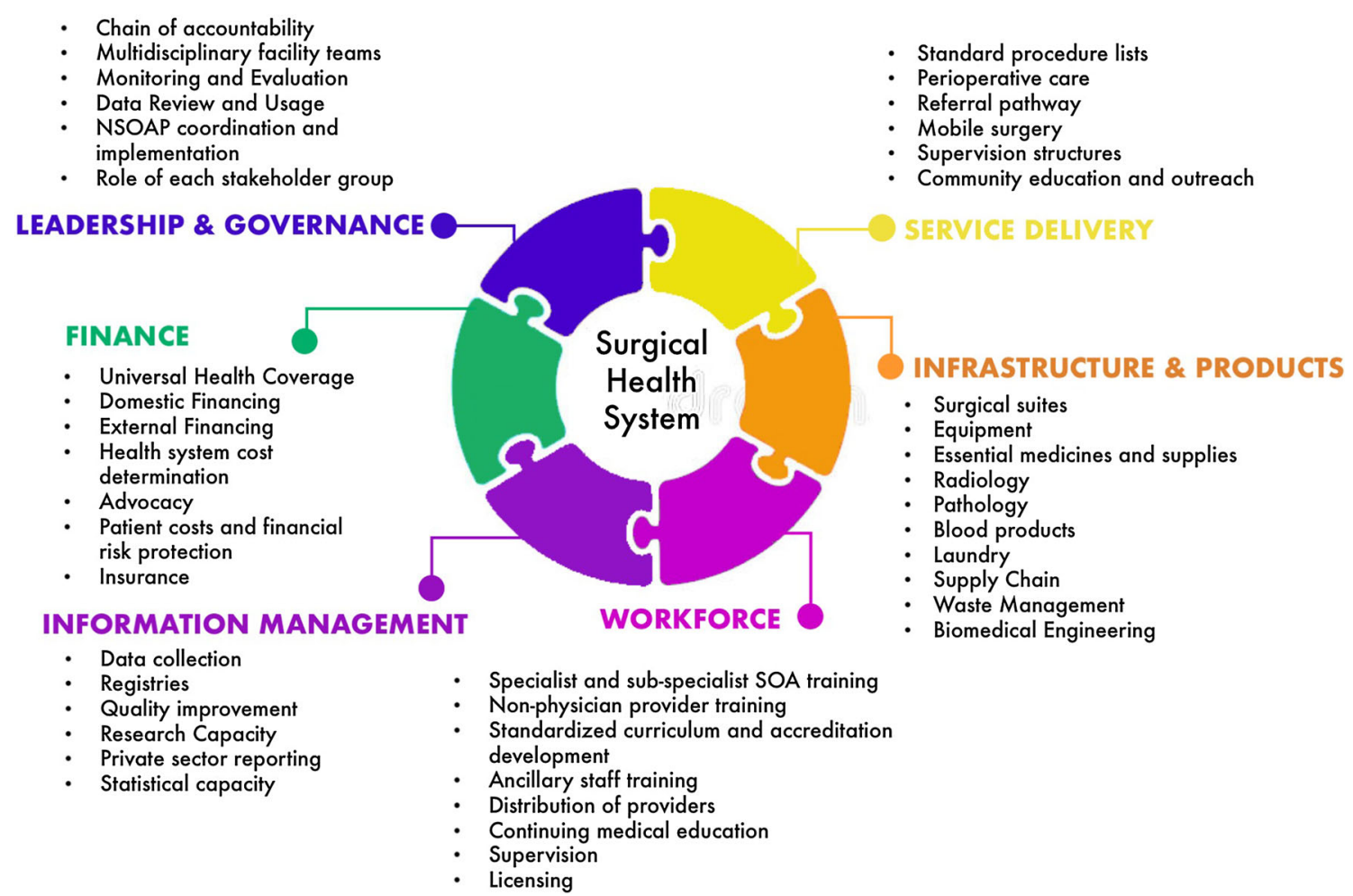

Fig. 1 Six domains of the surgical system and examples of associated areas of a national surgical, obstetric, and anesthesia plan (NSOAP). These interconnected domains and their subthemes must be developed simultaneously to achieve impact

\section{Benefits of planning}

The way to achieve this coordination is through national surgery, obstetric, and anesthesia plans (NSOAPs). National surgery, obstetric, and anesthesia plans provide a vision, along with costed and time-bound targets, of how actors within the SOA system will work together to systematically improve the SOA health system. Currently, five countries ${ }^{\mathrm{A}}$ have completed their NSOAPs and close to 20 more are in the initial stages or underway. The benefits of NSOAPs are four-fold.

\section{Coordination and efficiency}

Coordination of actors improves efficiency and impact. Not only must an NSOAP address each of the access facets, to be effective it must work on the entire health system defined by six domains (Fig. 1). By planning ahead, no single domain is being developed in isolation-e.g., building new operating rooms without considering how

\footnotetext{
${ }^{\text {A }}$ Countries with completed NSOAPs, at the time of writing of this editorial, are Senegal, Zambia, Ethiopia, Tanzania, and Rwanda.
}

Six domaines du système chirurgical et exemples de domaines associés d'un plan national pour les soins en chirurgie, obstétrique et anesthésie (NSOAP). Ces domaines interconnectés et leurs thèmes secondaires doivent être développés simultanément pour avoir un impact

they will be staffed or equipped, or training anesthesiologists without ensuring the essential drug supply chain. By planning for each of these multiples domains, the system endeavors to get the right patient in the right place at the right time, with the right staff, right equipment and supplies, and right skills for the right price. Coordination also improves the impact of each dollar spent, which is crucial if we are to address the $\$ 2.5$ trillion projected annual spending gap needed to meet the SDGs. ${ }^{8}$

The NSOAP provides a framework within which representatives of all sectors work towards a common goal to avoid duplication and wasted effort. Take, for example, two to three-day short courses covering basic obstetric anesthesia for non-physician anesthesia providers, a common package delivered internationally. ${ }^{9}$ The NSOAP framework can transparently ensure that this is a stated national priority, and that across all state and non-state actors, the courses are non-duplicative and are complemented by other longer term plans to improve the quantity and quality of the SOA workforce pipeline. Multiple actors complement different areas of need within the plan and, as such, have more impact than simply the sum of their parts. Coordination is especially 
important given efforts to strengthen SOA overlap with simultaneous efforts to develop other areas of the health system-e.g., programs to improve antibiotic supply chains or electricity at the rural hospital improves SOA care but also that of many other conditions.

\section{Visibility and accountability}

National surgery, obstetric, and anesthesia plans improve the visibility and accountability around SOA care within a national health system. A 2015 study of national health plans of Sub-Saharan Africa reported that $63 \%$ of plans had fewer than five mentions of surgery. ${ }^{10}$ By comparison, $95 \%$ have time-bound activities and targets to address human immunodeficiency virus infection, tuberculosis, and infant and maternal mortality. ${ }^{10}$ Developing an NSOAP requires political commitment for the plan to be driven by countries' ministries of health. Often, this is the first time surgery and anesthesia have entered the national strategic agenda for health systems planning. An example of this is Zambia, where the surgery has moved from barely being mentioned in the health strategic plan (HSP) to a key priority in their updated HSP following the creation of their NSOAP. ${ }^{11}$

\section{National priority setting}

An important benefit of the NSOAP process is that it ensures national priorities are set by those they affect. The process of NSOAP development requires engagement with multiple stakeholders across the SOA system from clinicians, ancillary staff, ministry of health, and finance departments before collectively agreeing on priorities, concrete actions to achieve those priorities, and accountability metrics against which to measure progress. By engaging the SOA community from front-line staff to the patients using the services, it allows their voices and opinions on health system priorities to be heard, and promotes agency amongst those who will ultimately be responsible for implementing the plan. Predefining priorities of front-line stakeholders can protect a health system from external groups seeking to influence national health priorities and ensure that non-state actors fit within the agenda of the country. This also improves efficiency as it can avoid multiple and repeated needs assessments by using common pre-agreed priorities to move directly towards solutions.

\section{Platform for investment and partnership}

National surgery, obstetric, and anesthesia plans can create a platform for investment and partnership. The completed
NSOAP should spell out costed and rationalized priorities. Ethiopia has successfully attracted partners to assist in the coordinated implementation of their NSOAP, whilst Tanzania has secured pooled international development assistance from their "basket fund" to exponentially expand sustainable formal anesthesia training. ${ }^{12,13}$ As more and more funding bodies move towards results based assistance, the transparent costing and evaluation metrics can open up opportunities for more partnership and funding. ${ }^{14}$

\section{National surgery, obstetric, and anesthesia plan process}

The process of creating an NSOAP is adapted to align with national protocols, and to date, most have followed a similar process. The NSOAP process begins with a commitment from the ministry of health to drive the NSOAP process. A broad cross-section of stakeholders including, but not limited to, ministry departments, specialist and non-specialist physicians, ancillary staff, training institutions, faith-based organizations, and nongovernmental organizations are then identified and engaged to understand their priorities for the SOA system. A baseline situational analysis that includes both literature review and facility assessments provides an overview of the current status of SOA care to allow evidence-based identification of needs and solutions as well as creating a baseline against which to assess the impact of the plan. The findings of the stakeholder engagement and situational analysis can then be synthesized into a draft of the plan that includes strategic objectives as well as concrete activities to achieve those objectives and time-bound targets to assess progress. The draft of the plan is then iterated amongst the stakeholders until consensus is achieved. It is then ready to be costed and approved internally within the ministry of health (Fig. 2). A step by step guide to this process with further information is available. ${ }^{15}$

\section{Implementation}

Ultimately, the measure of NSOAP success is not so much in how well it is written, but how well it is implemented. Although it is still too soon to judge the elements that make for a successful NSOAP, there are some early lessons to guide countries currently looking to develop NSOAPs. The successful implementation of NSOAPs includes, amongst many others, three key areas: political will and organization, funding, and data; and all three are codependent (Fig. 3). 


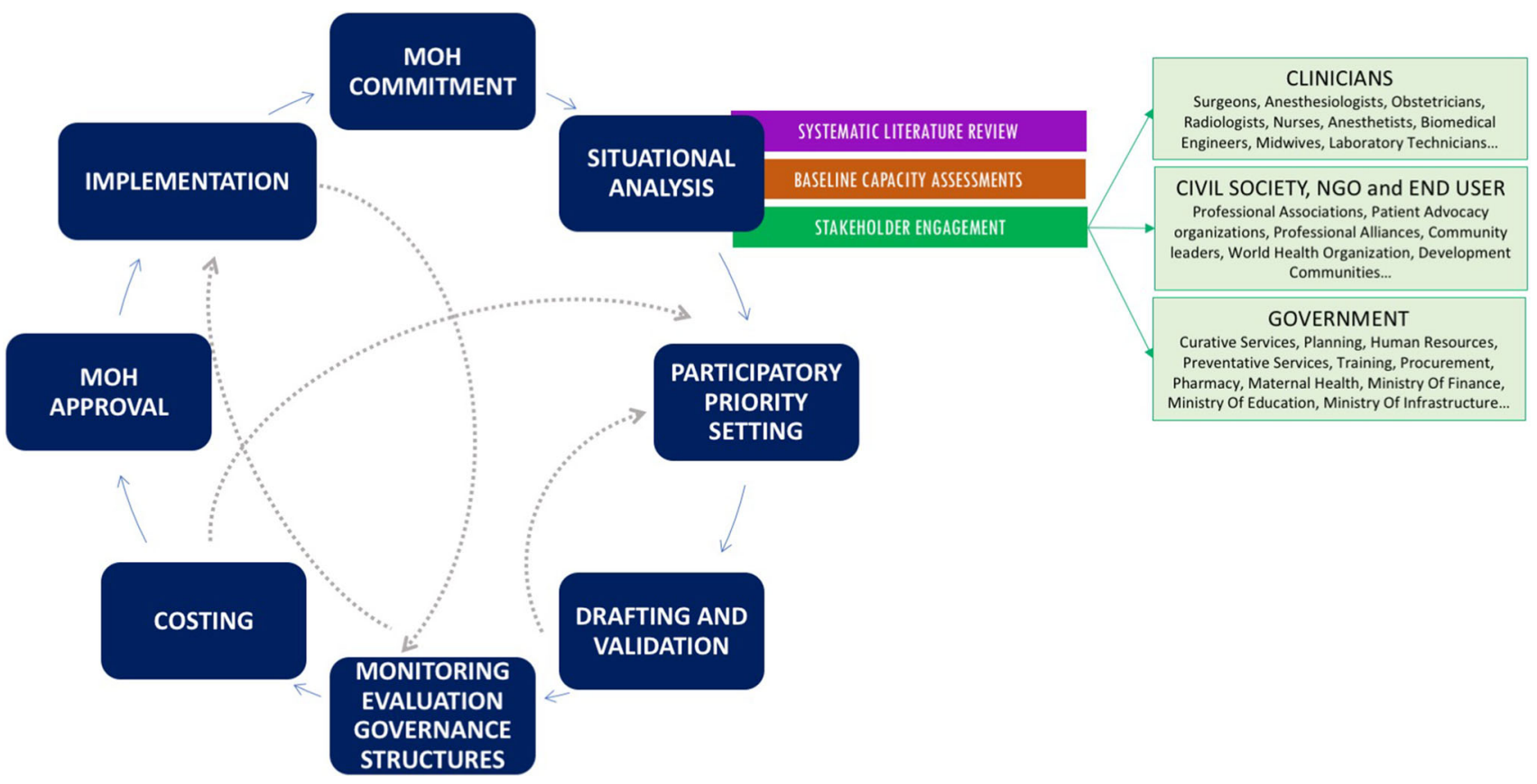

Fig. 2 Proposed steps for the development of national surgical, obstetric, and anesthesia plans. 1) The planning process starts with a commitment from the ministry of health to develop an NSOAP. 2) A comprehensive situational analysis is performed, including information from systematic literature review, on-the-ground baseline capacity assessments, and expert stakeholder knowledge and opinion. These data are aggregated to form the basis for evidence-based policy making. 3) A cross-section of key stakeholders are brought together to review information from the situation analysis and agree on priorities. 4) Those priorities are written up into a clear draft, including objective, activities, and outputs, which are then circulated back to the group for validation. 5) Once priorities are agreed, measurable, time-bound indicators are defined as part of a monitoring and evaluation framework. Governance structures of who will take responsibility for implementing each activity within the NSOAP are laid out. Chains of accountability to ensure that data from the monitoring and evaluation plan are reviewed and leveraged are agreed. 6) The activities including the monitoring and evaluation plan are costed. At this point, there may need to be a reprioritization with stakeholders to ensure that the final cost is attainable. 7) The final plan is then escalated through the formal ministry of health process until approval. 8) Implementation can then begin, iterated with information feedback from the monitoring and evaluation plan. $\mathrm{MOH}=$ ministry of health; NSOAP = national surgical, obstetric, and anesthesia plan

Political will and organization

To gain political will, it is crucial to align and integrate the NSOAP with the national HSP priorities. Integration into the national HSP is intimately linked to funding, as in many
Étapes proposées pour l'élaboration de plans nationaux de soins en chirurgie, obstétrique et anesthésie. 1) Le processus de planification commence par un engagement du ministère de la Santé pour l'élaboration d'un NSOAP. 2) Une analyse situationnelle complète est réalisée, incluant l'information tirée d'une analyse systématique de la littérature, des évaluations de terrain sur les capacités existantes et des connaissances et de l'avis expert de parties prenantes. Ces données sont rassemblées pour constituer la base de la prise de décision d'une politique basée sur des données probantes. 3) Un groupe transversal d'acteurs clés est réuni pour analyser l'information fournie par l'analyse situationnelle et se met d'accord sur les priorités. 4) Ces priorités sont rédigées dans une version préliminaire claire qui inclut l'objectif, les activités et les résultats; ce projet retourne alors au groupe et circule pour validation. 5) Une fois les priorités établies d'un commun accord, des indicateurs sont définis dans le temps dans le cadre d'un dispositif de suivi et d'évaluation. Des structures de gouvernance déterminant qui sera responsable de la mise en œuvre de chaque activité dans le cadre du NSOAP sont mises en place. Les parties prenantes se mettent d'accord sur des chaînes de responsabilités pour s'assurer que les données issues du plan de suivi et d'évaluation sont analysées et exploitées. 6) Les activités, y compris le suivi et le plan d'évaluation, sont chiffrées. À ce stade, il pourrait être nécessaire de modifier l'ordre des priorités avec les parties prenantes pour s'assurer que le coût final est réaliste et accessible. 7) Le plan final est alors transmis par les voies officielles du ministère de la Santé jusqu'à son approbation. 8) La mise en œuvre peut alors commencer, enrichie par le retour d'information du plan de suivi et d'évaluation. $\mathrm{MOH}=$ ministère de la Santé; NSOAP = Plan national pour les soins en chirurgie, obstétrique et anesthésie

countries, the national health budget is allocated through the national HSP. In Zambia, for example, elements from the NSOAP were integrated into the HSP, which allowed domestic funding from the Zambian government to be put into programs to expand surgical, anesthesia, and theatre nursing training. 


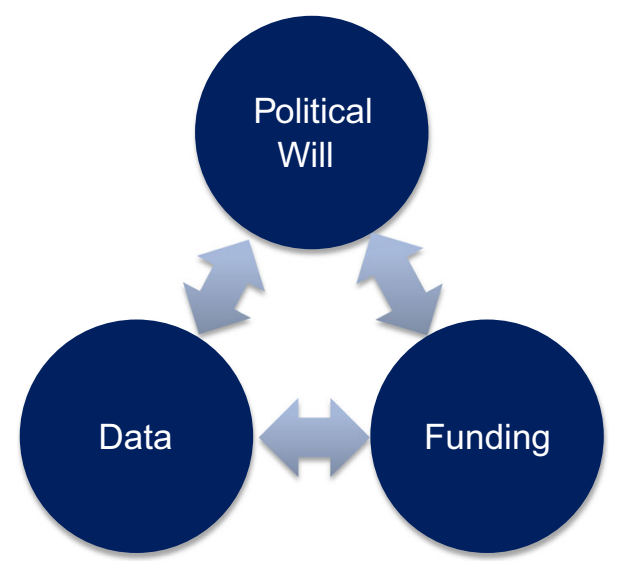

Fig. 3 Selected key elements of implementation success. Political will can generate the funding so crucial to the national surgical, obstetric, and anesthesia plan process. Good-quality data can make a convincing case to generate political will. It can also transparently feedback on the impact of funding creating a virtuous cycle of increased investment. If a health issue can attract additional funding, it is often regarded as a higher political priority. Although priority setting that is driven by funding availability is not what is aspired to, given limited resources and many competing demands for resources, it is often the reality

Éléments clés sélectionnés d'une mise en œuvre réussie. La volonté politique peut générer le financement crucial pour le processus de plan national pour les soins en chirurgie, obstétrique et anesthésie. Des données de bonne qualité peuvent faire la différence et faire naître cette volonté politique. Elles peuvent aussi influencer de manière transparente et permettre le financement par un cycle vertueux d'investissements croissants. Si un problème de santé peut attirer des financements supplémentaires, il est souvent considéré comme une priorité politique du plus haut niveau. Même si le cadre d'une priorité dictée par la disponibilité du financement n'est pas celui auquel on aspire, compte tenu des ressources limitées et des nombreuses demandes concurrentes, il représente souvent la réalité

Linked with sufficient political will, plans must have a clear governance with a chain of accountability from the ministry of health to the facility level, and vice versa. An example of this would be in Ethiopia where SOA representatives should be in place at each level of the health system. ${ }^{12}$ Given the amount of work required to implement an NSOAP, staff dedicated to SOA implementation are recommended early in the process, including at least one individual ultimately responsible and accountable for the NSOAP implementation. Accountability throughout the system must be evidencebased through robust monitoring and evaluation of data.

Funding

Without sufficient funding, the NSOAP implementation will fail. The NSOAP is designed to strengthen health systems, rather than vertical programs. Thus, each domain is interdependent. For it to have impact, a critical mass of the plan must be funded and implemented synchronously or else the other areas that are funded will have little impact. Plans must be adequately prioritized to ensure that the final cost of the plan is ambitious but attainable - e.g., in Tanzania, the cost is less than $3 \%$ of current health spend. ${ }^{16}$ The majority of funding will be domestic, require political will to secure, and rely on monitoring and evaluation to be sustained based on positive impact. In addition to domestic funding, many low-income countries will need external funding from private and international donor agencies. Domestic financing can begin a virtuous cycle as external donors look to leverage commitments by national governments to maximize impact rather than crowd out domestic responsibility. ${ }^{14}$

\section{Data}

To continue this momentum in SOA care, data will need to show that NSOAPs work both in terms of increasing visibility and financing of SOA care, and in the longer term, improve outcomes for patients within SOA care and more broadly across the health system. At present, there is a lack of high-quality implementation scientific data to show which programs are scalable on a national level and actually work. As more countries begin to complete their NSOAPs and implement programs, close tracking of success and failure is needed such that the global community can quickly learn and iterate their cyclical NSOAP plans and prove that SOA care is not complex beyond reach, but attainable through the cycle of planning, implementing, and monitoring. High-quality data reporting can improve accountability, improve political commitment by measuring progress and highlighting remaining challenges.

Worldwide, if there is to be an exponential increase in meaningful access to SOA care, a dramatic shift in the status quo will be required to improve the impact and efficiency of investments. National surgery, obstetric, and anesthesia plans bring the required health systems thinking to SOA care and integrate it into the wider health agenda. As more countries develop NSOAPs, focus should move towards understanding what makes for successful strategies to attract funding, collect high-quality data, and ultimately improve outcomes for surgical and obstetric patients.

\section{Défendre la cause des plans nationaux pour les soins en chirurgie, obstétrique et anesthésie}

Les 17 objectifs de développement durable (SDG sustainable development goals) des Nations Unies ciblent un large éventail de conditions humaines dans le monde, incluant la pauvreté, l'équité, le développement, les genres, 
la santé et la prospérité. ${ }^{1}$ Chaque année, 16,9 millions de vies sont perdues à cause de problèmes pouvant être réglés par une intervention chirurgicale, 12,3 mille milliards de dollars de productivité économique seront perdus entre 2015 et 2030 à cause de maladies liées à la chirurgie, l'anesthésie et l'obstétrique (CAO) et, chaque année, 81 millions de personnes sont confrontées à des dépenses aux conséquences catastrophiques en recherchant des soins chirurgicaux. ${ }^{2}$ Considérant que les soins d'urgence, de chirurgie essentielle et d'anesthésie ont été inclus dans la couverture de maladie universelle (CMU) en 2015, et que les soins de CAO recoupent six des 17 SDG, nous avons besoin d'une action massive en faveur de la santé publique pour atteindre les cibles de CMU et de SDG. ${ }^{3}$ Les efforts doivent porter sur l'ensemble du système chirurgical, du niveau communautaire jusqu'aux soins tertiaires complexes et spécialisés en déployant une stratégie intéressant toutes les branches professionnelles et tous les domaines du système de santé. Les Droits humains et les arguments économiques d'un investissement dans les soins de $\mathrm{CAO}$ sont clairs : il y a maintenant une obligation à agir.

\section{Accès aux soins chirurgicaux et anesthésiques}

La véritable notion d' " accès » aux soins de CAO est complexe. Il y a plusieurs facteurs interdépendants à arrimer avant que l'accès aux soins ne devienne réalité pour les patients. Tout d'abord, les soins doivent être disponibles quand un patient arrive dans un établissement de santé où des services sont proposés. Ces services doivent être assurés par des prestataires compétents et de qualité suffisante pour obtenir les résultats désirés. De plus, les soins doivent être utilisables, ce qui signifie que les patients doivent pouvoir surmonter de multiples obstacles, tels que l'éducation, la géographie et le coût abordable qui les empêcheraient d'aller et d'obtenir les soins disponibles. Enfin, le critère de soins abordables est une épée à double tranchant, car il peut devenir un obstacle empêchant certains individus de rechercher, d'atteindre ou de recevoir des soins et, pour ceux qui les reçoivent, cela peut les faire basculer dans la pauvreté, entraînant un échange pervers entre santé et prospérité. ${ }^{4}$

Compte tenu du vrai sens de «l'accès », il devient évident que des problèmes existent à différents niveaux dans quasiment tous les systèmes de soins de santé et pas seulement dans les pays à revenu faible. Dans certains des pays à revenu faible, la disponibilité et la qualité des soins, leurs aspects pratiques et abordables peuvent tous être un problème en soi. Cela se reflète, par exemple, dans le fait que les patients sont encore presque deux fois plus susceptibles de mourir après une chirurgie dans certains pays africains, suggérant le peu d'éducation sanitaire des patients entraînant une consultation tardive et des soins peu disponibles et de mauvaise qualité. ${ }^{5}$ Les pays à revenu élevé ont également des problèmes d'accès aux soins. Ainsi, plus de $70 \%$ des 30 millions de patients, approximativement, non assurés aux États-Unis sont exposés au risque de dépenses catastrophiques en cas de soins pour traumatisme. ${ }^{6}$ En outre, pour ce qui concerne la qualité des soins, le taux de mortalité maternelle est en hausse dans ce pays : les mères ont un risque $55 \%$ plus grand de mourir aux États-Unis qu'en Lybie. ${ }^{7}$ Si l'accès aux soins de CAO doit être amélioré, tous les aspects d'un véritable « accès » doivent être abordés simultanément; la coordination est donc un élément essentiel.

\section{Les avantages de la planification}

Le moyen de parvenir à cette coordination passe par des plans nationaux pour les soins en chirurgie, obstétrique et anesthésie ou NSOAP (National Surgery, Obstetric, and Anesthesia Plans). Les plans nationaux pour les soins en chirurgie, obstétrique et anesthésie procurent une vue d'ensemble avec des cibles chiffrées et déterminées dans le temps précisant comment les acteurs travailleront ensemble au sein d'un système de soins de CAO pour améliorer systématiquement ces derniers dans le système de santé. Actuellement, cinq pays ${ }^{\mathrm{A}}$ ont complété leurs NSOAP et près d'une vingtaine d'autres en sont à différents stades. Les avantages des NSOAP sont quadruples.

\section{Coordination et efficience}

La coordination des acteurs améliore l'efficience et l'impact. Non seulement un NSOAP doit aborder chacun des aspects de l'accès aux soins, mais pour être efficace, il doit agir sur tout le système de santé défini par six domaines (Figure 1). En planifiant, aucun domaine n'est développé de manière isolée. On ne construit pas, par exemple, de nouvelles salles d'opération sans se demander comment elles seront équipées ou si on aura le personnel nécessaire; de même, on ne forme pas d'anesthésiologistes sans assurer la chaîne d'approvisionnement en médicaments essentiels. En planifiant chacun de ces nombreux domaines, le système s'engage à amener un patient donné au bon endroit et au bon moment, avec le personnel adapté, l'équipement adéquat et les fournitures correspondantes, les compétences requises pour un prix correct. La coordination améliore également l'impact de chaque dollar dépensé, ce qui est crucial si nous devons

\footnotetext{
A Countries with completed NSOAPs, at the time of writing of this editorial, are Senegal, Zambia, Ethiopia, Tanzania, and Rwanda.
} 
combler les dépenses annuelles projetées de 2,5 mille milliards de dollars nécessaires pour répondre aux SDG. ${ }^{8}$

Le NSOAP procure un cadre dans lequel les représentants de tous les secteurs travaillent pour un objectif commun en évitant la redondance et le gaspillage d'énergie. Prenons, par exemple, les cours des deux à trois jours couvrant l'anesthésie obstétricale de base pour des prestataires d'anesthésie non-médecins (ces programmes sont couramment délivrés sur le plan international). ${ }^{9} \mathrm{Le}$ cadre du NSOAP peut garantir de façon transparente qu'il s'agit d'une priorité nationale et que tenant compte de tous les acteurs nationaux et extra nationaux, les cours ne sont pas répétitifs et sont complétés par des projets à plus long terme visant à améliorer le nombre et la qualité des effectifs dans la filière CAO. De multiples acteurs comblent différents domaines où les besoins se font sentir dans le plan et, en tant que tels, ont plus d'impact que la simple addition de leurs rôles. La coordination est particulièrement importante compte tenu des efforts faits pour renforcer le chevauchement des soins $\mathrm{CAO}$ avec les efforts simultanés faits pour développer d'autres domaines du système de santé : par exemple, les programmes visant à améliorer les chaînes permettant la disponibilité en antibiotiques ou l'électricité dans un hôpital rural pour améliorer ces soins de CAO, mais aussi ceux de nombreuses autres affections.

\section{Visibilité et responsabilités}

Les plans nationaux pour les soins en chirurgie, obstétrique et anesthésie améliorent la visibilité et la responsabilisation entourant les soins de CAO au sein d'un système national de santé. En 2015, une étude des plans de santé nationaux en Afrique subsaharienne a indiqué que ces plans contenaient moins de cinq mentions de chirurgie. ${ }^{10}$ En comparaison, $95 \%$ avaient des activités et des cibles visant l'infection par le virus de l'immunodéficience humaine, la tuberculose et la mortalité maternelle et infantile. ${ }^{10}$ L'élaboration d'un NSOAP nécessite un engagement politique envers le plan qui doit être piloté par les ministres de la Santé des pays concernés. C'est souvent la première fois que la chirurgie et l'anesthésie entrent dans les programmes stratégiques nationaux pour la planification des systèmes de santé. La Zambie en est un bon exemple. La chirurgie, jusque là à peine mentionnée dans un plan stratégique de santé (PSS), est devenue une priorité majeure dans le PSS actualisé qui a suivi la création de leur NSOAP. ${ }^{11}$

Établissement des priorités nationales

Un avantage important du processus de NSOAP est qu'il assure que les priorités nationales sont établies par ceux qu'elles touchent. Le processus d'élaboration d'un NSOAP nécessite l'engagement de nombreux acteurs dans tout le système des soins de CAO, depuis les cliniciens jusqu'au ministre de la Santé en passant par le personnel auxiliaire et les départements financiers avant de parvenir à un accord collectif sur les priorités, les actions concrètes à entreprendre pour mener à bien ces priorités et les paramètres d'évaluation permettant de mesurer les progrès. En impliquant la communauté $\mathrm{CAO}$, des personnels de première ligne jusqu'aux patients ayant recours à leurs services, leur avis et opinions sur les priorités du système de soins peuvent être entendus et être mis de l'avant par ceux qui seront responsables de la mise en œuvre du plan. Prédéfinir les priorités des acteurs de première ligne peut protéger un système de santé contre des groupes extérieurs cherchant à influencer les priorités sanitaires nationales et assurer que les acteurs extérieurs à l'état s'alignent sur le programme du pays. Cela améliore également l'efficience en évitant possiblement des évaluations multiples et répétées des besoins grâce à l'utilisation de priorités communes préacceptées pour se diriger directement vers des solutions.

Plate-forme pour les investissements et le partenariat

Les plans nationaux pour les soins en chirurgie, obstétrique et anesthésie peuvent créer une plate-forme pour les investissements et le partenariat. Les NSOAP complétés devraient comporter des priorités chiffrées et rationalisées. L'Éthiopie a réussi à attirer des partenaires pour l'aider dans la mise en œuvre de son NSOAP pendant que la Tanzanie s'est assurée d'une aide arrimée au développement international à partir de leur «panier de fonds » pour une expansion exponentielle de la formation formelle et durable en anesthésie. ${ }^{12,13}$ Lorsque de plus en plus d'organismes de financement passent à une aide basée sur des résultats, l'évaluation des coûts transparente et les paramètres d'évaluation peuvent ouvrir des opportunités supplémentaires de partenariat et de financement. ${ }^{14}$

\section{Processus des plans nationaux pour les soins en chirurgie, obstétrique et anesthésie}

Le processus de création d'un NSOAP est adapté pour s'aligner sur les protocoles nationaux et, à ce jour, la plupart d'entre eux ont suivi un processus semblable. Le processus de NSOAP commence par un engagement du ministère de la Santé à le piloter. Un large éventail d'acteurs incluant, mais sans s'y limiter, des départements ministériels, des médecins spécialistes et non spécialistes, du personnel auxiliaire, des organismes de formation, des organisations confessionnelles et des organisations non 
gouvernementales a été identifié et invité à connaître leurs priorités pour le système de soins CAO. Une analyse situationnelle initiale incluant à la fois une étude des publications et l'évaluation des établissements procure une vue d'ensemble de l'état actuel des soins de CAO; cela permet une identification basée sur des données probantes des besoins et solutions, et aussi la création d'un point de départ à partir duquel l'impact du plan peut être évalué. Les constatations de l'engagement des acteurs et de l'analyse situationnelle peuvent alors être synthétisées dans une version préliminaire du plan qui inclut les objectifs stratégiques ainsi que les activités concrètes permettant d'atteindre ces objectifs et les cibles limitées dans le temps pour évaluer les progrès. La version préliminaire du plan est alors revue par les principales parties prenantes jusqu'à ce qu'un consensus soit obtenu. Il peut alors être chiffré et approuvé en interne au sein du ministère de la Santé (Figure 2). Un guide étape par étape de ce processus est disponible avec de l'information supplémentaire. ${ }^{15}$

\section{Mise en ouvre}

Enfin, le succès d'un NSOAP ne repose pas tant sur la qualité de sa rédaction que sur la réussite de sa mise en œuvre. Bien qu'il soit encore trop tôt pour juger les éléments qui font la réussite d'un NSOAP, on peut tirer les premières leçons pour guider les pays qui cherchent actuellement à en élaborer. La mise en œuvre réussie d'un NSOAP inclut, parmi beaucoup d'éléments, trois points clés : une volonté politique et de l'organisation, un financement et des données; ces trois aspects sont interdépendants (Figure 3).

\section{La volonté politique et l'organisation}

Pour obtenir une volonté politique, il est crucial d'aligner le NSOAP avec les priorités nationales du PSS et de l'y intégrer. L'intégration dans le plan stratégique de santé est intimement liée au financement, car dans de nombreux pays le budget national de la santé est alloué via un PSS. En Zambie, par exemple, des éléments du NSOAP ont été intégrés dans le PSS, permettant qu'un financement local par le gouvernement zambien aille aux programmes visant à élargir la formation en chirurgie, anesthésie et en soins infirmiers de salle d'opération.

Liés à une volonté politique suffisante, les plans doivent disposer d'une gouvernance claire avec une chaîne de responsabilité fonctionnant dans les deux sens : du ministre de la Santé au niveau de l'établissement et vice versa. C'est le cas de l'Éthiopie où des représentants des soins de CAO devraient être en place à chaque niveau du système de santé. ${ }^{12}$ Compte tenu de la masse de travail nécessaire pour mettre en œuvre un NSOAP, le personnel dédié à la mise en œuvre des soins de CAO est recommandé tôt dans le processus, incluant au moins un individu qui soit le responsable ultime de l'implémentation du NSOAP. La responsabilité dans l'ensemble du système doit reposer sur des données probantes grâce à un contrôle et à une évaluation des données.

\section{Financement}

Sans financement suffisant, la mise en œuvre du NSOAP échouera. Le NSOAP est conçu pour le renforcement des systèmes de santé, plutôt que comme des programmes verticaux. Ainsi, chaque domaine est interdépendant. Pour que cela ait un impact, il faut qu'une masse critique du plan soit financée et implémentée de manière synchrone, faute de quoi les autres domaines financés n'auront que peu d'impact. Les priorités des plans doivent être correctement établies pour s'assurer que leur coût final soit ambitieux mais accessible (par exemple, en Tanzanie, le coût est inférieur à $3 \%$ des dépenses de santé actuelles). ${ }^{16}$ L'essentiel du financement proviendra du pays lui-même, nécessitera une volonté politique et reposera sur un suivi et une évaluation qui devra être soutenue en se basant sur un impact positif. En plus du financement national, de nombreux pays à revenu faible auront besoin de financements externes provenant de donateurs privés et d'agences internationales. Le financement local peut enclencher un cycle vertueux, car les donateurs extérieurs cherchent à s'appuyer sur les engagements des gouvernements nationaux pour maximiser leur impact plutôt que d'affaiblir les responsabilités locales. ${ }^{14}$

\section{Données}

Pour maintenir cette dynamique dans les soins de CAO, les données devront montrer que les NSOAP fonctionnent à la fois en termes de plus grande visibilité et de plus grand financement des soins de CAO; elles devront aussi montrer à plus long terme qu'elles améliorent le sort des patients recevant des soins de $\mathrm{CAO}$ et que le système de santé en tire un profit global. À l'heure actuelle, nous manquons de données scientifiques de grande qualité sur l'implémentation pour montrer quels programmes peuvent être mis à l'échelle sur un niveau national et lesquels fonctionnent réellement. Alors que plus de pays commencent à boucler leur NSOAP et à mettre en place des programmes, un suivi étroit des succès et échecs est nécessaire de façon à ce que la communauté internationale puisse rapidement apprendre et adapter leurs plans de NSOAP cycliques et prouver que les soins de CAO ne sont pas complexes au point d'être inaccessibles, mais qu'ils sont au contraire accessibles par des cycles de planification, 
mise en œuvre et suivi. Le retour de données de grande qualité peut améliorer la responsabilisation, améliorer l'engagement politique en mesurant les progrès et en mettant en lumière les défis restant à surmonter.

S'il doit y avoir dans le monde une augmentation exponentielle à un accès significatif à des soins de $\mathrm{CAO}$, il sera nécessaire de bousculer considérablement le statu quo pour améliorer l'impact et l'efficacité des investissements. Les plans nationaux pour les soins en chirurgie, obstétrique et anesthésie amènent la réflexion nécessaire des systèmes de santé vers les soins de CAO et les intègrent dans un programme de soins de santé élargi. Au fur et à mesure que davantage de pays élaborent des NSOAP, il faut maintenant chercher à comprendre ce qui fait les stratégies gagnantes pour attirer des fonds, collecter des données de grande qualité et, finalement, améliorer la santé des patients chirurgicaux et obstétricaux.

Conflicts of interest None declared.

Editorial responsibility This submission was handled by Dr. Hilary P. Grocott, Editor-in-Chief, Canadian Journal of Anesthesia.

Funding Isabelle Citron receives the Frank Knox Scholarship at Harvard University John G Meara and The Program in Global Surgery and Social Change at Harvard Medical School receives funding from General Electric Foundation.

Conflits d'intérêts Aucun déclaré.

Responsabilité éditoriale Cet article a été traité par le $\mathrm{D}^{\mathrm{r}}$ Hilary $\mathrm{P}$. Grocott, Rédacteur en chef, Journal canadien d'anesthésie.

Financement Isabelle Citron bénéficie de la Frank Knox Scholarship à l'université Harvard. John G Meara et le programme de chirurgie et de changement social «Program in Global Surgery and Social Change » de la Harvard Medical School reçoivent un financement de la fondation General Electric.

\section{References}

1. United Nations Department of Economic and Social Affairs. The sustainable development goals report. United Nations 2016: Available from URL: https://www.un.org/development/desa/ publications/sustainable-development-goals-report-2016.html (accessed October 2018).

2. Meara JG, Leather AJ, Hagander L, et al. Global surgery 2030: evidence and solutions for achieving health, welfare, and economic development. Lancet 2015; 386: 569-624.
3. World Health Organization. Strengthening emergency and essential surgical care and anaesthesia as a component of universal health coverage Report by the Secretariat. Provisional agenda item 5.1-May 2014. Available from URL: http://apps. who.int/gb/ebwha/pdf_files/EB135/B135_3-en.pdf (accessed October 2018).

4. Shrime MG, Dare AJ, Alkire BC, O'Neill K, Meara JG. Catastrophic expenditure to pay for surgery worldwide: a modelling study. Lancet Glob Health 2015; 3(2): S38-44.

5. Biccard BM, Madiba TE, Kluyts HL, et al. Perioperative patient outcomes in the African Surgical Outcomes Study: a 7-day prospective observational cohort study. Lancet 2018; 391: 158998.

6. Scott JW, Raykar NP, Rose JA, et al. Cured into destitution: catastrophic health expenditure risk among uninsured trauma patients in the United States. Ann Surg 2018; 267: 1093-9.

7. The World Bank. Maternal mortality ratio (modeled estimate, per 100,000 live births) I Data. Available from URL: https://data. worldbank.org/indicator/sh.sta.mmrt (accessed October 2018).

8. World Economic Forum. There's a \$2.5 trillion development investment gap. Blended finance could plug it. July 2016. Available from URL: https://www.weforum.org/agenda/2016/07/ blended-finance-sustainable-development-goals/ (accessed October 2018).

9. Livingston P, Evans F, Nsereko E, et al. Safer obstetric anesthesia through education and mentorship: a model for knowledge translation in Rwanda. Can J Anesth 2014; 61: 1028-39.

10. Citron I, Chokotho L, Lavy C. Prioritisation of surgery in the National Health Strategic Plans of Africa: a systematic review. World J Surg 2016; 40: 779-83.

11. Ministry of Health. Zambia National Health Strategic Plan 20172021. Available from URL: http://www.nationalplanningcycles. org/sites/default/files/planning_cycle_repository/zambia/ zambianhsp.pdf (accessed October 2018).

12. Burssa D, Teshome A, Iverson K, et al. Safe surgery for all: early lessons from implementing a national government-driven surgical plan in Ethiopia. World J Surg 2017; 41: 3038-45.

13. Mwalimu $U$. Watumishi wa afya 200 kupatiwa mafunzo ya utoaji dawa ya usingizi kuokoa maisha wajawazito (Tanzania). Available from URL: https://twitter.com/umwalimu/status/ 1005029552836489216?lang=en (accessed October 2018).

14. Global Financing Facility. Maximizing Impact: How the GFF Trust Fund Complements and Adds Value to IDA (Factsheet) 2017. Available from URL: https://www.globalfinancingfacility. org/sites/gff_new/files/documents/GFF-IDA_EN_Web.pdf (accessed October 2018).

15. Albutt $K$, Citron I, Sonderman $K$, et al. National Surgical Obstetric and Anaesthesia Planning: Process and Consensus Recommendations-2018; Available from URL: https://ghd-dubai. hms.harvard.edu/files/ghd_dubai/files/2018-dubai_nsoap_policy_ brief.pdf? $\mathrm{m}=1525866968$ (accessed October 2018).

16. The United Republic of Tanzania. Ministry of Health Community Development, Gender, Elderly and Children. Republic of Tanzania National Surgery, Obstetric and Anaesthesia Plan 2018-2025 - 2018. Available from URL: https://docs.wixstatic. com/ugd/d9a674_4daa353b73064f70ab6a53a96bb84ace.pdf (accessed October 2018). 